\title{
Strategies of Awareness of the Retirement in Employees of a Mexican Company
}

\author{
María de los Ángeles Aguilera Velasco, María de Lourdes Marrero Santos, \\ Martín Acosta Fernández, Teresa Margarita Torres López
}

Universidad de Guadalajara, Guadalajara, Mexico

Email: aaguileracd@hotmail.com

How to cite this paper: de los Ángeles Aguilera Velasco, M., de Lourdes Marrero Santos, M., Fernández, M.A. and López, T.M.T. (2018) Strategies of Awareness of the Retirement in Employees of a Mexican Company. Open Journal of Social Sciences, 6, 119-131.

https://doi.org/10.4236/jss.2018.66012

Received: September 29, 2017

Accepted: June 11, 2018

Published: June 14, 2018

Copyright $\odot 2018$ by authors and Scientific Research Publishing Inc. This work is licensed under the Creative Commons Attribution International License (CC BY 4.0).

http://creativecommons.org/licenses/by/4.0/

(c) (i) Open Access

\begin{abstract}
An intervention study was made with an initial self-evaluation and a summative evaluation for the purpose of fostering awareness of the retirement process in employees nearing retirement at a Mexican waterworks company. Sensitization strategies consisted of giving two successive interactive conferences. Data were gathered using the SQA-E metacognitive format with two open questions and during the plenary sessions. The 92 employees over 55 years old who participated were divided into five groups. Each group received the same information presented in a completely similar manner. A thematic analysis was made of the data to gather information about prior and subsequent knowledge and expectations. Employees successfully learned about the historical and politico-economic situation of retirement, devised their own definition of retirement and learned about the need to plan and become prepared. They wanted to stay active, improve their health and quality of life, strengthen their social networks, participate socially and manage their income. They decided that they would retire voluntarily, they would have an economic plan, would establish a positive attitude and peace of mind, would try to be happy and enjoy retirement to the fullest and prepare for old age by learning to live alone. A link between the university and the company was forged. We suggest continuing to promote preparation with two sensitization conferences because they help employees to become aware of retirement, to want to plan for it and to stay active, to involve family members and colleagues, and to use the comprehensive evaluation of large groups.
\end{abstract}

\section{Keywords}

Sensitization, Educational Preparation, Retirement, Employees

\section{Introduction}

Preparation for retirement is an essential topic for study. In the past, retirement 
as a topic had no major importance because life expectancy was short; nevertheless, increasingly more people will retire and live for many more [1] At least one out or every three of these people will have increased anxiety and stress levels, experience difficulties in adapting to a new role and may suffer from the retirement syndrome with physical, psychological and social manifestations, including insomnia, digestive disorders, anxiety, pessimism, loss of relationships and loneliness [2] [3] [4] [5] [6].

Employees nearing retirement make for a vulnerable high-risk population, given that retirement only has a positive outcome for people's wellbeing if it is voluntary [7] [8], if the employees have a favorable attitude [9], if they have the social support of friends [10] and if they make a financial plan and a life plan [11].

Employees need to be prepared educationally to prevent such problems. Nevertheless, educational preparation for retirement is not as easy as it sounds because employees have no natural desire to attend the courses offered to them and because some people believe it is almost offensive to be told what to do with the spare time they have rightfully earned [9]. On the other hand, there are scarce experiences and works published on preparing for retirement. Only two interventions carried out in Chile stand out, where they applied cognitive-behavioral strategies to improve satisfaction with life [12], as well as in Mexico on training in strategies for occupying free time and offering guidance about government administrative procedures [13], and to improve the quality of life with neuro-linguistic programming [14], in Brazil on building projects for the future [15], in Spain on becoming aware of a protagonist role in society after retirement [16] and to offer the possibility of participating as mediators in different voluntary action projects with social services [17], in the United Kingdom in exploring the relation between contemporary visual art with identity and a sense of wellbeing [18], and in the United States, on financial education [19] [20].

It is therefore deemed important to embark on the arduous task of educational preparation for retirement with a sensitization strategy that has raised awareness in retirees and those nearing retirement as well as in their relatives and colleagues [21] [22]. Despite the implicit difficulties, preparing for retirement should be approached with the sense of urgency warranted by the seriousness of the topic, given the physical, psychological and social alterations undermining retirees' quality of life.

The goals of educational sensitization are to: 1) motivate an individual and collective reflection on their role within the problems of retiring, 2) help to decipher the origins of the problems and understand the causes, 3) raise critical awareness, 4) create interest in social participation, 5) facilitate shedding myths and false beliefs, and 6) provoke a change of mentality, attitudes and practices. It is also a key factor in making further educational actions possible [23] [24]. It should be planned according to people's experiences and implemented briefly through interactive conferences showing results comparable to those of longer 
programs [25].

Educational sensitization consists of four steps, the first of which is a diagnosis of the participants' knowledge and expectations. Self-evaluation is considered proper for large groups. The next step is planning to define the objectives of the conferences based on the diagnosis. The third step is an interactive implementation of the conferences while the fourth and final step is self-evaluation, enabling one to ascertain what lessons participants learned and their new expectations. Accordingly, the purpose of the study was to promote sensitization of the retirement process in employees nearing retirement in a Mexican company.

\section{Methodology}

\subsection{Type of Study and Design}

An intervention study was made starting with an initial self-evaluation (prior to the conferences) and a summative evaluation (upon completion of the conferences) focused on the participants' knowledge and expectations [26] in a multiuse hall at the Guadalajara, Jalisco waterworks, between August and November 2016. The self-evaluation was based on two models: criterial-naturalist [27] while the other model centered on people's needs [28]. It was based to a large extent on personal interpretation and on becoming familiar with the informants' subjective concerns by using comprehensive tools [29] [30] [31] [32] [33].

\subsection{Sensitization Strategies}

Sensitization strategies consisted of two conferences given one after the other with a one-week interval between them. They were interactive and progressed according to the participants' interests. Participants shared personal experiences and expressed their opinions and/or questions when they thought it was important.

The conference "Understanding my Retirement", used previously in other studies with a few retirees and people nearing retirement and their relatives and colleagues [21] [22], addressed six topics: definitions of the concept of retirement, factors intervening in retirement, the effects of retirement on health, the politico-economic situation of retirement, contributions of science to the topic of retirement, and some results of international and local research were presented. The first part of the SQA-E metacognitive instrument was applied for the initial self-evaluation at this conference; half an hour prior to the conference people wrote what they knew and wanted to know about retirement. The final evaluation was made by using the second part of the format upon conclusion of the conference, for people to state lessons learned and new expectations.

The conference "101 Tips for a Satisfactory Retirement", given for the first time, touched on 11 topics: the benefits of preparing for retirement, the advantages of an early retirement, the right to refuse retirement, the importance of jubilant good byes, fulfillment in spiritual matters, the joy of living with peace of mind, the satisfaction of social relationships, wellbeing and health in this new 
stage, financial prosperity in retirement, the positive side of vulnerable situations, and quality old age. Conference contents were taken from a book of the same name [34]. A reflection format designed by the authors and based on two open questions at the end of the conference was used for evaluating the conference. The employees wrote down the tip that seemed the most important to them and explained why they thought it was interesting. The plenary technique was also applied [35] for socializing the overall experience.

\subsection{Participants}

A total of 105 employees attended the conferences, and 92 employees 55 years and older participated in the study. Of the total 105 employees, 13 stopped participating because their evaluations were incomplete at some time during the process. The average age of the participants was 58 (minimum age 43 , maximum 78 ); $16 \%$ were women, $76 \%$ were married, $9 \%$ single and $4 \%$ lived in common law marriage. Average seniority at the company was 21 years. The majority were healthy although some employees had diabetes and high blood pressure. Many had college studies (34\%), the rest has technical studies, high school, grade school or incomplete grade school studies (in the case of the operators).

Employees were separated into five groups. Each group attended twice, the first time at the "Understanding my Retirement" conference and the second time at the "101 Tips for a Satisfactory Retirement" conference. Implementation lasted 20 hours distributed among 10 two-hour long work sessions. There were $20 \%$ more participants (equivalent to 18 employees) at the "Understanding my Retirement" conference than at the "101 Tips for a Satisfactory Retirement" conference. The groups received the same information presented in a completely similar way.

\subsection{Data Analysis}

A thematic analysis was made of the "Understanding my Retirement" conference in search of information about knowledge and expectations prior to the conference as well as afterwards. As for the "101 Tips for a Satisfactory Retirement" conference, the tip chosen by each participant was analyzed. Data gathered from both conferences were captured in Windows Excel software.

Information from the first conference was gathered on a spreadsheet with four columns: what I know, what I want to know, what I learned and my new expectations. Specific analyses of the (previous and final) expectations and of acquired knowledge were made afterwards, based on the categorization of prior knowledge. Information from the second conference was gathered on another spreadsheet and later analyzed according to the kind of tip mentioned by the employees.

\subsection{Ethical Considerations}

The study complied with the guidelines of the National Bioethics Commission. 
The rights of the informants were protected according to the Declaration of Helsinki [36] in its most recent edition, and the General Law on Health regarding Health Research Matters in Mexico [37], Articles 16 through 23. The project was registered with the Research Coordinating Office at the University Center for Health Sciences (CUCS) and the Workers' Health and Safety Research Institute, both pertaining to the University of Guadalajara (UDG).

This study is part of the macro-project "Healthy Company" where, thanks to a general agreement, use of data taken from scientific publications is allowed. UDG has absorbed the expenses incurred in this study. The project was also submitted to company authorities who gave their approval to carry it out. All employees attended and participated voluntarily and gave their oral informed consent. Once the purpose of the study was explained to them, they were assured that their information would be kept confidential and they could terminate their participation whenever they thought it was pertinent.

\section{Results}

\subsection{Initial Knowledge about Retirement}

Six kinds of initial knowledge were found prior to implementing both strategies. First place was a group of employees who knew nothing about retirement: " $I$ ' $m$ not really informed about this topic, I only know I am approaching retirement but I don't know how the process is carried out and what is coming". A second type of initial knowledge was found in some employees who had some information about the age and number of years employees needed to be able to retire. "Retirement comes upon turning 60 years old or 30 years of service". A third kind of knowledge involved employees who knew very little about retirement. "Just some comments". A fourth kind of prior knowledge was knowing that retirement is a labor right. "It is a right that all employees earn, to rest, after devoting part of their life to a company. It includes healthcare".

In fifth place, there were employees who had a prior definition of retirement: " As its name implies, it is a stage after working that should be received jubilantly. It means no longer working during a determined schedule, it is changing our routine. One should go from one stage to the next as part of the normal cycle of human development. I should pass on to the next stage emotionally balanced, knowing that it is completely normal in my development to continue on. I should expect different changes, my life will change, an occupational and economic change". In sixth place, some employees assured that they knew retirement was negative and they feared it: "Truth be told, I am afraid because of so many things that have been said, mainly due to the new reforms that have been enacted that create confusion among people. I hope these talks clear up several questions I have about my pension".

\subsection{Initial Expectations}

Five kinds of initial expectations were also found before the conferences. The 
first concern was wanting to know everything about retirement: "I want to know everything to be well informed. I don't want to draw a blank when it's my turn to retire". This expectation was expressed by all employees except for those who had their own definition of retirement and those who feared retirement. The second expectation was wanting to know about the requirements and administrative procedures for retiring: "Seniority, required age, people who can help me, who I can go to, quotas, savings withdrawals, fees paid since 1974, changes to pension laws, amount of sick leave, documents required for retirement, knowing whether I will have any problems for retiring, the amount of my pension, and procedures".

All the employees expressed this last concern so together with the company we invited an expert in these matters to explain everything dealing with retirement requirements and administrative procedures. The expert spoke before the five groups to give specific information according to each employee's age and seniority and to answer all their questions about administrative arrangements.

The third expectation was the need to know their rights and obligations upon retiring: "Economic and recreational advantages, benefits, why they no longer want to retire at 60, knowing the difference between being pensioned and being retired'. Their rights upon retirement was a topic of interest to almost all, except for those employees who knew very little about retirement. The topic of obligations only interested those participants who had a prior definition of retirement. The fourth concern was wanting to know how they could keep active outside their home: "What activities will I be able to perform? How to look for an activity outside my home? How to manage the change from being active to being inactive?'. This expectation was only of interest to those employees who knew nothing, who had information about age requirements and who had an initial definition of retirement.

The fifth and last initial expectation was wanting to know how to prepare for this stage: "How to cope with the changes in this stage of my life? What to do to live my retirement fully? How to overcome the emotional aspect of my life? Learning from the experiences of people before and after this process. Possible health consequences that may occur and how to cope with them. How to act and endure retirement? What I have to do to maintain a healthful life style? How to organize my time? What I should do to improve, adapt and take advantage of my time?". This concern was shared by all the employees.

\subsection{Lessons Learned}

Upon conclusion of the first conference, five kinds of lessons learned by the employees were found. The employees learned about the historical and politico-economic situation of retirement: "Retirement is a privilege in our country because only $6 \%$ retire. We live in a very tragic scenario; my old age security is on shaky grounds, the government has become the enemy instead of having retirees' backs. I'd rather die first. I didn't know the government had stolen the retirement fund. I feel uncertain. The pension one receives is the average wage 
over the past five years at work. Many people are misinformed and need training". Employees who knew little and those who were afraid did not manage to acquire this knowledge.

The employees also devised definitions of retirement that they could explain in their own words. For instance, employees who knew nothing defined it as follows: "It is the third stage of my life in which I can feel stressed, alone and depressed". It meant the following for those employees who at first only knew about age and seniority requirements: "It is a reward for so many years of effort, or work commitment. It is the opportunity to carry out certain doable projects that we have left pending along the way and to resume mental activities and take care of our soul and our health. It is a change of life status. It is a new stage of our life". The employees who at first knew little said: "It is a temporary process to take care of my health and enjoy the benefits. One needs rest, good company and an active occupation".

Employees who knew from the start that retirement is a right defined it as follows: "It could be good but it also has consequences. Life after retirement depends on different factors and specific needs. Some mental or physical health problems may crop up". Employees who had a prior definition added: "You need to adapt to a new way of life and be reconciled with new relationships. I learned about historical, physical and emotional aspects, the stages, effects, changes and prevention". Those who were fearful from the outset learned the following: "Retirement is saying good-bye to work but not to human activities". In third place, employees managed to learn about the importance of planning: "You need to plan to avoid negative health and societal situations, to lead a healthy life. You have to continue planning even though you're retired, to plan your spare time and reorganize your social life. I'll have to think about it and define a healthy life plan". All the employees succeeded in learning about the importance of planning except for those who were fearful and those who knew nothing from the onset.

In fourth place, almost all the employees disclosed they had learned they should prepare for retirement from the workplace: "You have to prepare for retirement physically, mentally and with your family. My psychological preparation is quite important and necessary to erase any fantasies about retirement and to bring my plans down to earth. I need to be aware of my own retirement. I must be prepared because I'm afraid of becoming sick'. Only those employees who were initially afraid failed to learn the importance of preparation. In fifth and last place, they learned what they needed to achieve wellbeing: "Take advantage of our time doing something useful. Perform activities I couldn't do before due to lack of time, such as reading, swimming, walking and learning. Spend more time with my spouse. Not lose touch with my friends and relatives. Live life to the fullest. Take care of my health. Value myself as a person and figure out what I want to be and what I can do. Keep active to not fall into depression. Be at peace with my life. Take care of myself to enjoy the remaining years of life. Begin a new life". 


\subsection{Final Expectations}

Upon conclusion of the conference on understanding retirement, besides expressing the lessons learned, the employees iterated new concerns. Those who initially knew nothing about retirement had new physical, mental, social and financial expectations: "To get prepared and organized, to adapt, understand and enjoy my new life. To keep active. Live a long time. Begin the administrative procedures for retirement. Learn to spend time with my spouse and children. Make a life plan. Clear up my thoughts about retirement. Accept it. Have a positive attitude. Be aware of each stage of retirement. Learn how to manage solitude. Maybe start a business". They expressed the following summary of this process: "I learned things I had never heard of before".

The people who initially were aware of the retirement age and the number of years of work required mentioned new final physical as well as mental and social expectations, including altruistic actions: "Be prepared. Be active. Do exercise. Take care of my health. Plan my retirement. Value my family more. Keep on developing communication. Continue to participate in community life. Perform social activities. Analyze and prepare for my future. My retirement is going to be a life full of things to learn and to share with others". Their final phrase was: "I have to sensitize myself". Upon conclusion of the conference, the employees who initially knew little about the topic wound up establishing physical and mental goals: "Learn about the topic. Do exercise. Accept Plan. Improve the quality of my life. Have a dignified old age. Exert mental and emotional control over the process". One of them said: "It would be marvelous to retire".

The employees who knew from the beginning that retirement is a right posed the following mental and physical expectations: "Plan for and program my retirement. Be active to get the most out of my time. Increase social coexistence. Manage my money so as to cover my needs". They came to the following conclusions: "Life goes on". On the other hand, the employees who initially had their own definition of retirement listed the following at the end of the process: "Retire soon. I must get prepared and adapt. Visualize retirement. Make a life plan. Spend time with my loved ones. Devote more time to myself. I will help others to have a healthy community and neighbors. Keep active. Have a positive retirement with health, harmony and goals. I'm going to spend my retirement at sea level. I wouldn't want to have marital problems". Lastly, those employees who feared retirement had positive yet ambiguous expectations: "I have positive clear expectations for myself and my retirement".

\subsection{Tips Chosen for Experiencing Satisfactory Retirement}

Out of the 101 tips offered to the employees, they chose the 14 tips shown in Table 1.

\section{Discussion}

Coincidences were found with some authors [2] [3] [4] [5] [6] in that at least one out of three employees knew nothing about retirement and without 
Table 1. Tips chosen by participants to achieve satisfactory retirement.

\begin{tabular}{lll}
\hline \multicolumn{1}{c}{ Before retirement } & \multicolumn{1}{c}{ During retirement } & \multicolumn{1}{c}{ Preparing for old age } \\
\hline & $\begin{array}{l}\text { Take care of my health and money to have wellbeing and } \\
\text { enjoy more. Arrive at old age in one piece, self-sufficient }\end{array}$ & I must learn to live alone to get to \\
Not retire if I have problems (depression, burnout & and independent, able to cover my needs without & know myself, find the meaning of \\
syndrome or debts) because I wouldn't be happy & $\begin{array}{l}\text { depending on others until the end of my life. You need } \\
\text { discipline. I must do it because I have very expensive } \\
\text { that way. }\end{array}$ & $\begin{array}{l}\text { my life, be coherent and achieve } \\
\text { chronic diseases, if what I want is to spend more time }\end{array}$
\end{tabular}

I should retire voluntarily at the proper time; it should be my decision; I won't let them make me retire. Think it through and define it well, calmly, to not feel guilty. Be sure it will bring me better quality of life and peace of mind.

Pre-retirement is the foundation for better quality of life: have an awareness of retirement, that it is life-changing, but to take it positively and follow each of the tips.

Most important is to plan my retirement. It will help me do what I like, to live peacefully, to enjoy more, to be happy, to have good health, good financial and emotional stability, to keep active, to have a prosperous future, an incentive to continue living and studying and to strengthen my life. Have short, medium and long-term plans, to include my spouse because I need his/her support.

Prepare for our retirement: to be physically, emotionally and spiritually well, to enjoy our time and keep active.

Have an economic plan to be able to travel and go to meetings, take care of my health, have fun and have money for old age. Maybe invest in a business. Treat sicknesses in public institutions to not deplete my savings. Leave everything to my spouse because children can squander their inheritance. with my family.

Build a positive attitude to not have any problems. Try to

be happy and enjoy retirement $100 \%$, because if I'm

happy, those around me will also be happy.

Have peace of mind when making important decisions because decisions made during depression will lead you astray to an uncertain future. You have to be certain about what you can count on, and have clear goals. A healthy retirement requires you to be sound of mind.

Keep active and be an altruist. Look for a pleasant activity that you like and do it to the fullest extent, to pay I will live my old age as a bachelor back to society some of what it has given me. Participate because there will actually be no in activities outside home and take trips. Take advantage one to help me with anything. It of leisure time because you will have time to spare. Don't will be expensive and I won't be stop having activities so as to avoid depression. Physical able to activity will help you be self-sufficient. I can exercise, do afford it. yoga, swim and get together with my children and siblings which I don't do very often.

Social relationships help me have social wellbeing and enjoy the free time that I couldn't when I worked. Be with and have fun with my wife because thanks to her I will get to the finish line and retire. Retirement is good for both of us.

Spend more time with my family to establish the communication that we hadn't had for so many years due to paying more attention to my job. Work takes up $100 \%$ of your time. I can strengthen family ties, talk about my old age.

sensitization, maybe they would have trouble adapting to a new role. The employees in this study recognized that their retirement would bring them wellbeing if it were voluntary, if they had positive attitudes and if they designed a life plan and an economic plan, as other authors have pointed out [7] [8] [9] [10] [11]. Nevertheless, no coincidence was found regarding the social support of friends that would allow them to ease away from the workplace because the employees of this study did not mention it, unlike what other researchers have found [10].

Similar to a finding by another author [9], educational preparation did not turn out to be as easy as it seemed and there was a $20 \%$ drop in the employees' interest in the second conference in comparison with the first strategy imple- 
mented. We found, as have other authors with different intervention strategies [12] [13] [14] [15] [16], greater satisfaction with life, a desire to occupy free time and to know about administrative procedures, interest in improving quality of life, in creating projects for the future and in having awareness about retirement. Coincidence was found in a few employees with other authors [17] with regards to wanting to participate in voluntary action projects.

Just as in other investigations [21] [22], the educational sensitization conference "Understanding my Retirement" succeeded in making them aware of retirement and planning. Other proposals of educational interventions posed by other authors [23] [24] [25] were also met. Employees understood the importance of being prepared before, during and after retirement at the 100 Tips conference.

\section{Conclusions}

The goal of sensitizing and raising awareness of retirement in 92 employees approaching retirement was achieved. They were helped to decipher, reflect on and socialize their knowledge and expectations about retirement and it also helped them understand the continuous retirement process, to be motivated to take on a protagonist role, to raise their awareness about retiring from work, to stimulate their interest in social participation, to facilitate shedding myths and false beliefs and to begin changing their mentality, attitudes and practices.

Starting with the "Understanding my Retirement" conference, the employees learned about the historical and politico-economic situation of retirement, devised their own definition of retirement and learned what is needed to plan and get prepared. They also wanted to remain active, improve their health and quality of life, strengthen their social networks, participate socially and manage their income.

After the "101 Tips for a Satisfactory Retirement" conference, the employees decided that they would only retire voluntarily, avoid retirement if some health problem were detected and would be aware of their retirement; they would plan for it and be prepared. They also commented that once retired, they would remain active, have an economic plan, achieve wellbeing by taking care of their health and money, build a positive attitude and that they would enjoy peace of mind. They would enjoy the spare time and their family. They would try to be happy and enjoy retirement to the fullest. They would become prepared for old age by learning how to live alone.

The conclusion is that the study also allowed the start of a company-university link regarding preparation for retirement in the environment where the study was made. This link turned out to be useful for those employees nearing retirement and opened the door to future possibilities. Lastly, we suggest that companies prepare their employees nearing retirement with sensitizing conferences, given that it is possible to successfully raise awareness of retirement, for them to want to plan for it and keep active. We also recommend involving friends and families in future interventions because their participation and preparation are 
pertinent. We further suggest applying a comprehensive evaluation of qualitative studies that would allow one to investigate large groups and gather data from their viewpoint.

\section{References}

[1] Moragas, R., Rivas, P., Cristofol, R., Rodríguez, N. and Sánchez, C. (2006) Estudio: prevención dependencia. Preparación para la jubilación-dos. Parc Cientific, Barcelona.

[2] Braithwaite, V. and Gibson, D. (1987) Adjustment to Retirement: What We Know and What We Need to Know. Aging and Society, 7, 1-18.

https://doi.org/10.1017/S0144686X00012265

[3] Bossé, R., Aldwin, C., Levenson, R. and Workman-Daniels, K. (1991) How Stressful Is Retirement? Fundings from the Normative Aging Study. Journal of Gerontology: Psychological Sciences, 46, 9-14. https://doi.org/10.1093/geronj/46.1.P9

[4] Jensen-Scott, R. (1993) Counseling to Promote Retirement Adjustment. Career Development Quarterly, 41, 257-267.

https://doi.org/10.1002/j.2161-0045.1993.tb00376.x

[5] Moragas, R. (2012) Jubilación siglo XXI. Palibrio, Barcelona.

[6] Theriault, J. (1994) Retirement as a Psychosocial Transition: Process of Adaptation to Change. International Journal of Aging and Human Development, 38, 153-170. https://doi.org/10.2190/YQAU-H8ER-2N4K-HATM

[7] Crowley, J.E. (1986) Longitudinal Effects of Retirement on Men's Well-Being and Health. Journal of Business \& Psychology, 1, 95-113. https://doi.org/10.1007/BF01018806

[8] Quine, S., Wells, Y., De Vaus, D. and Kendig, H. (2007) When Choice in Retirement Decisions Is Missing: Qualitative and Quantitative Findings of Impact on Well-Being. Australasian Journal on Ageing, 26, 173-179. https://doi.org/10.1111/j.1741-6612.2007.00251.x

[9] Rodríguez, N. (2006) Actitudes hacia la jubilación. Interdisciplinaria, 24, 5-42.

[10] Chiesa, R. and Sarchielli, G. (2008) Prepararse para la jubilación. El papel del apoyo social en la gestión de la ansiedad. Revista de Psicología del Trabajo yde las Organizaciones, 24, 365-388. https://doi.org/10.4321/S1576-59622008000300006

[11] Hewitt, A., Howie, L. and Feldman, S. (2010) Retirement: What Will You Do? A Narrative Inquiry of Occupation-Based Planning for Retirement: Implications for Practice. Australian Occupational Therapy Journal, 57, 8-16. https://doi.org/10.1111/j.1440-1630.2009.00820.x

[12] Skoknic, V. (1998) Efectos de la preparación psicológica para la jubilación. Revista Intervención Psicosocial, 7, 155-168.

[13] Pérez, A., Padilla, P., Loría, J., Herrera, N.J., Ortiz, S., Girón, A.T. and Villafranca, R.M. (2006) Proyecto de vida posterior a la jubilación en el personal de enfermería de un hospital de segundo nivel. Revista Cubana de Enfermería, 22, 1-11.

[14] Montalvo, J., Nápoles, O., Espinosa, M. and González, S. (2011) Efectos cualitativos de una técnica de PNL en la dependencia emocional de pareja. Revista electrónica de Psicología Iztacala UNAM, 14, 1-23.

[15] Penna, H. and Costa, B. (2008) Projetos de Futuro na Aposentadoria: uma discussão fundamentada pela Orientação Profissional em Psicologia. Perspectivas en Psicología: Revista de Psicología y Ciencias Afines, 5, 37-46. (In Portuguese) 
[16] Pérez, R. (2006) Aportes del trabajo social en los cursos de preparación a la jubilación. Acciones e Investigaciones Sociales, 22, 429. https://dialnet.unirioja.es/servlet/articulo? codigo $=170274$

[17] Domínguez, C. and Vera, C. (2000) Jubilación y prejubilación. Un modelo de participación con prejubilados. Acciones e Investigaciones Sociales, 11, 113-124. https://papiro.unizar.es/ojs/index.php/ais/article/view/185

[18] Goulding, A. (2012) Lifelong Learning for People Aged 64+ within the Contemporary Art Gallery Context. Educational Gerontology, 38, 215-227. https://doi.org/10.1080/03601277.2010.544569

[19] Clark, R.L., Maki, J.A. and Morrill, M. (2014) Can Simple Informational Nudges Increase Employee Participation in a 401(k) Plan? Southern Economic Journal, 80, 677-701. https://doi.org/10.4284/0038-4038-2012.199

[20] Gresham, L. (2012) Fun with Financial Education. Employee Benefit Adviser, 10, 62-64.

[21] Aguilera, M.A., Pérez, J.J., Delgado, D.D., Contreras, M.I., Acosta, M. and Pozos, B.E. (2013) Educational Preparation of Older Adults and Their Families for Retirement. Advances in Applied Sociology, 3, 237-245. https://doi.org/10.4236/aasoci.2013.36032

[22] Aguilera, M.A., Pérez, J.J. and Pozos, B.E. (2014) Educational Intervention to Sensitize Future Retirees and Work Colleagues about Retirement from Work. Social Sciences, 3, 208-216. https://doi.org/10.11648/j.ss.20140306.14

[23] Chicharro, R. and Maza, J. (2008) Programas de educación y sensibilización. Tiempo de $\mathrm{Paz}, \mathbf{8 9}, 153-156$.

[24] eQual (2011) Módulo II: La sensibilización como estrategia de cambio. Fondo Social Europeo/Malabaristas del Tiempo, Andalucía.

[25] Pick, S., Leenen, I., Givaudan, M. and Prado, A. (2010) Yo quiero, yo puedo... prevenir la violencia: Programa breve de sensibilización en el noviazgo. Salud Mental, 33, 153-160.

[26] Casanova, M.A. (1999) Manual de evaluación educativa. La Muralla S.A., Madrid.

[27] Guba, E.G. and Lincoln, I.S. (1989) Fourth Generation Evaluation. SAGE, California.

[28] Stake, R.E. (2013) Evaluación comprensiva y evaluación basada en estándares. Graó, Barcelona.

[29] Morse, J.M. and Field, P.A. (1995) Qualitative Research Methods for Health Professionals. SAGE, California.

[30] Patton, M.Q. (1987) How to Use Qualitative Methods in Evaluation. SAGE, California.

[31] Pérez, G. (1994) Investigación cualitativa: Retos e interrogantes. La Muralla, Madrid.

[32] Taylor, S.J. and Bogdan, R. (1992) Introducción a los métodos cualitativos de investigación. Paidós, Barcelona.

[33] Wilson, H.S. and Hutchinson, S.A. (1991) Triangulation of Qualitative Methods: Heideggerian Hermeneutics and Grounded Theory. Qualitative Health Research, 1, 263-276. https://doi.org/10.1177/104973239100100206

[34] Aguilera, M.A., Acosta, M. and Pozos, B.E. (2014) 101 consejos para una jubilación satisfactoria: Aportaciones científicas y su aplicación práctica. Editorial Universitaria, Guadalajara.

[35] Garrido, Luque-Ribelles and García-Ramírez (2013) La investigación-acción participativa como estrategia de intervención psicosocial. In: Buades, J. and Giménez, C., 
Eds., Hagamos de nuestro barrio un lugar habitable. Manual de intervención comunitaria en barrios, Fundación CeiMigra, Valencia.

[36] Asociación Médica Mundial (2008) Declaración de Helsinki: Principios éticos para las investigaciones médicas en seres humanos. Asamblea General de la Asociación Médica Mundial, Seúl.

[37] Secretaria de Salud (1984) Reglamento de la Ley General de Salud en Materia de Investigación para la Salud. Secretaria de Salud, Distrito Federal. 